\title{
Cooling Catheters for Selective Brain Hypothermia
}

W e read with interest "Endovascular Cooling Catheter for Selective Brain Hypothermia: An Animal Feasibility Study of Cooling Performance" by Cattaneo et al. ${ }^{1}$ The authors achieved mild brain hypothermia by using a novel indwelling cooling catheter. We appreciate the authors' acknowledgment of our work in selective brain cooling. ${ }^{2}$ However they may have misunderstood the TwinFlo catheter evaluated in our study (ThermopeutiX, San Diego, California). The TwinFlo inner coaxial balloon catheter is 9.5F, with an inner diameter of $2.0 \mathrm{~mm}$ ( 0.080 inches). This is well within the lumen size needed to perform simultaneous mechanical stent-retriever thrombectomy during selective brain cooling.

Reduction in brain metabolic demand is related to the depth of hypothermia. ${ }^{3}$ Brain cooling using the authors' device was only mild $\left(-4.2^{\circ} \mathrm{C}\right.$ to $\left.-4.5^{\circ} \mathrm{C}\right)$ and took $>2$ hours to achieve. On the other hand, endovascular cold blood perfusion seems better able to achieve the very low temperatures $\left(25^{\circ} \mathrm{C}-26^{\circ} \mathrm{C}\right)$ necessary to avert ischemic stroke and can do so very rapidly $\left(<30^{\circ} \mathrm{C}\right.$ in a median of 15 minutes). We demonstrated a substantial reduction in stroke volume in our large-animal model, despite starting cooling well into the reperfusion phase and after 3 hours of focal ischemia.
Disclosures: Thomas K. Mattingly—RELATED: Grant: Heart and Stroke Foundation,* ThermopeutiX, ${ }^{*}$ Comments: HSF GIA 7273; ThermopeutiX provided the TwinFlo catheters and assisted in data collection on catheter performance. Stephen P. Lownie-Travel/Accommodations/Meeting Expenses Unrelated to Activities Listed: Vice-President, Canadian Neurosurgery Society. *Money paid to the institution.

\section{REFERENCES}

1. Cattaneo G, Schumacher M, Maurer C, et al. Endovascular cooling catheter for selective brain hypothermia: an animal feasibility study of cooling performance. AJNR Am J Neuroradiol 2015 Dec 24. [Epub ahead of print] CrossRef Medline

2. Mattingly TK, Denning LM, Siroen KL, et al. Catheter based selective hypothermia reduces stroke volume during focal cerebral ischemia in swine. J Neurointerv Surg 2015 Feb 12. [Epub ahead of print] CrossRef Medline

3. Lougheed WM, Kahn DS. Circumvention of anoxia during arrest of cerebral circulation for intracranial surgery. J Neurosurg 1955;12: 226-39 CrossRef Medline

(iD)T.K. Mattingly Neurosurgical Associates Richmond, Virginia (D).M. Pelz (1) S.P. Lownie London Health Sciences Centre London, Ontario, Canada 